\title{
Haeme-oxygenase 1 expression in rat pancreatic beta cells is stimulated by supraphysiological glucose concentrations and by cyclic AMP
}

\author{
J. C. Jonas ${ }^{1}$ - Y. Guiot ${ }^{2}$ - J. Rahier ${ }^{2}$ - J. C. Henquin ${ }^{1}$ \\ ${ }^{1}$ Unit of Endocrinology and Metabolism, Faculty of Medicine, University of Louvain, Brussels, Belgium \\ ${ }^{2}$ Service of Pathology, Faculty of Medicine, University of Louvain, Brussels, Belgium
}

\section{Diabetologia (2003) 46:1234-1244}

The authors' affiliations had been printed incorrectly and should have been printed as written above.
Published online: 30 March 2004

(C) Springer-Verlag 2004

The online version of the original article can be found at http://dx.doi.org/10.1007/s00125-003-1174-9

J. C. Jonas ( $)$

Unit of Endocrinology and Metabolism, Faculty of Medicine, University of Louvain, Brussels, Belgium

E-mail: jonas@endo.ucl.ac.be 